\title{
The evaluation of alveolar fractures of trauma patients in Iran
}

\author{
Farhad Ghorbani ${ }^{1}$, Mohammad Khalili² and Hanie Ahmadi ${ }^{2 *}$
}

\begin{abstract}
Background: Alveolar bone plays a vital role in mastication and supporting the teeth. The alveolar process is one of the most challenging regions of facial bone to reconstruct due to the deformity involves both hard and soft tissues. However, the etiology, gender, and age distribution vary between different regions, cultures, and countries. This study aims to investigate the prevalence of alveolar trauma in Shahid Rajaee Hospital, Shiraz, Iran, for three years.

Methods: In a retrospective cross-sectional study, patients with alveolar fractures referred to Shahid Rajaei Hospital in Shiraz were included in the study. Age, sex, site of alveolar fractures, and etiology factors of trauma explored. The collected data was analyzed by SPSS software. Mean \pm SD calculated for the inferential statistics, and the data compared using Chi-square and Exact Fisher. A p-value of $<0.05$ was considered statistically significant with a $95 \%$ reliability.

Results: A total of 165 patients had alveolar fractures in this study. We found that the most common cause of alveolar fracture was road accidents (32.3\%) and the lowest reason was violence (9\%). Most people with alveolar trauma were male and in the 21-30 years. The prevalence of mandibular and maxillary alveolar fractures was 17.61 and 17.01\%, respectively, with the most anterior area of injury.

Conclusion: Alveolar trauma is one of the most common injuries among trauma patients. Early diagnosis and treatment plans are necessary to reduce the complications of facial trauma. Early training for a young adult is essential to prevent the severity of trauma.
\end{abstract}

Keywords: Alveolar, Fracture, Trauma, Maxilla, Mandible

\section{Background}

Trauma is any damage to vital tissues caused by physical, chemical, or biological factors, and it can occur exclusively or combined with other injuries [1]. The etiology of trauma is different from one country to another still, road accidents, interpersonal violence, falling, and accident during the sport are the most common etiological factors of maxillofacial trauma [2]. Age, sex, and alcohol consumption are highly associated with injuries and severity of them [3].

\footnotetext{
*Correspondence: hanieah199@gmail.com

2 Student Research Committee, Shiraz University of Medical Sciences,

Shiraz, Iran

Full list of author information is available at the end of the article
}

The oral cavity accounts for only 5 percent of the total body, and about 1 percent of all body trauma confined to this region [4]. Facial bone and skin are more prone to trauma due to their anterior position, and the mandible is the most fractured bone associated with dental and soft tissue injuries $[5,6]$. Craniofacial trauma expected at all ages, but it is less common in children and also, injuries are less severe in young children than in older ones [3, 7].

Maxillofacial injuries can occur as an isolated injury or may accompanied by multiple injuries in other parts of the body [8]. A high percentage of trauma patients suffer from alveolar fractures, including $32 \%$ of dental injuries, $27 \%$ of soft tissue injuries, and $1 \%$ of jaw bone fractures [9]. facial fractures include midface fractures-Le fort I, II, III, alveolar fractures in the maxilla and mandible, and 
mandible fractures including body, angle symphysis, para symphysis, and condyle [10].

Alveolar bone plays an important role in mastication and supporting the teeth. Alveolar fractures can categorized into the area surrounding a single tooth or regional type [11]. Loss of alveolar bone mostly occurs after severe traumatic events such as sports injury, violence, or accident. The alveolar process is one of the most challenging regions of facial bone to reconstruct due to the deformity involves both hard tissues and mucosa in mobile and moist conditions [12]. Alveolar fractures involve with displacement or fracture of teeth, the fracturing of bone, and injuring of soft tissue including abrasions, lacerations, and contusions [13, 14]. A radiograph should be taken when the signs of alveolar fractures are detected, and the gold standard for assesing facial injuries is Computed Tomography (CT) imaging [15]. There are some treatment choices in alveolar fractures, but the treatment chosen is depending on the patient's conditions; however, in most cases, open reduction with the internal fixation is preferred, and the few cases managed by closed reduction [16]. Studies recommended wire fixation for 4 to 6 weeks after alveolar fractures [17].

In Iran, the number of deaths caused by trauma increase due the urbanization and industrialization [18]. Basal bones of the mandible and maxilla reconstructed correctly, but rehabilitation of alveolar bone should considered for fixed and removable prosthetics, including, costly interventions such as bone grafting. Epidemiological study of alveolar trauma provides valuable information about the problems that occurred and successful management. Injuries of the jaws, including alveolar fractures, present in a small number of trauma patients, but the treatment of such injuries are too difficult to reconstruct. This study aims to investigate the prevalence of alveolar fracture in Shahid Rajaee Hospital, Shiraz, Iran, for three years.

\section{Methods}

\section{Population and design}

The Oral and Maxillofacial Surgery Center at Rajaee Hospital, Shiraz University of Medical Sciences, Shiraz, Iran, provides maxillofacial trauma treatment for many people in the Fars province.

This retrospective cross-sectional matched-control study done on all patients who had been referred to Shahid Rajaei Hospital, Trauma Center, between, 2016, to 2020. In this study, all individuals of different ages were examined, and there was no age limit.

Written informed consent was obtained from the participants and their anonymity was guaranteed. The study protocol was approved by the institutional research board (IRB) and the medical ethics committee of the Shiraz University of Medical Sciences by the IRB number1399.081REC.AL IR. SUMS.DENT.

All information was collected by reviewing the files in the archives during the mentioned years. The list of patients was prepared from the Hospital Information System (HIS), archived files, and CT images were assessed.

Inclusion criteria included all trauma patients of any age and sex who had referred to Shahid Rajaei Trauma Centers in Shiraz, completed the medical records, and consented to participate in the study. The exclusion criteria were prior maxillofacial surgeries, and inadequate imaging, and medical records of treatment or follow-up visits.

In the CT scan of the patient, various fractures, including fractures of different areas of the face, jaw, and alveolar process were recorded.

Age, sex, the etiological factors of trauma, and the site of the alveolar fractures were evaluated. The total number of patients with alveolar fractures and the anatomical location of the fractured jaw (anterior, posterior, and anterior-posterior) were measured.

The cause of trauma was divided into five main categories (i) car accident; (ii) motorcycles accident; (iii) violence; (iv) falling; and (v) others, which included domestic accidents, suicide attempts, pathological fractures, occupational accidents, accidents with animals, an accident during sports, fractures caused by teeth extraction and unknown etiology.

\section{Data gathering and analysis}

Data were analyzed using the Statistical Package for Social Sciences (SPSS, version. 22.0, SPSS Inc., Chicago, IL, USA).

Mean \pm SD was calculated for the inferential statistics and the data were compared using Chi-square and Exact Fisher. A p-value of $<0.05$ was considered statistically significant with a $95 \%$ reliability.

\section{Results}

In the three years of this study, 477 patients were diagnosed with maxillofacial trauma, and 375 (78.6\%) of whom were male, $102(21.3 \%)$ were female and the difference was statistically significant (chi-squared test, $p$ value $<0.005)$. Among them, 165 (34.5\%) had alveolar trauma. The mean age of male patients was $08 / 10 \pm 58 / 26$ years, female $13 / 11 \pm 03 / 30$ years, and this difference was statistically significant ( $\mathrm{p}$-value $=0.006$ ). facial trauma was more frequent in the age group of $21-30$ years $(n=190$, $39.8 \%)$ followed by below 20 years $(\mathrm{n}=145,30.3 \%)$, and $31-40$ years $(n=92,19,3 \%)$. The most common cause of alveolar fracture was due to car accidents $(\mathrm{n}=154,32.3 \%)$ 
Table 1 Demographic data and etiology of maxillofacial trauma

\begin{tabular}{lll}
\hline Variables & Number & Percentage \\
\hline Gender & 375 & \\
Male & 102 & 78.6 \\
Female & & 21.3 \\
Age & 145 & \\
Below 20 & 190 & 30.3 \\
21-30 & 92 & 39.8 \\
$31-40$ & 32 & 19.3 \\
$41-50$ & 18 & 6.70 \\
Over 50 & & 3.77 \\
Etiology & 146 & \\
Motorcycle accident & 154 & 30.6 \\
Car accident & 58 & 32.3 \\
Falling down & 43 & 12.2 \\
Violence & 73 & 9 \\
Other & & 15.3 \\
\hline
\end{tabular}

and the lowest cause was related to violence $(n=43,9 \%)$ (Table 1).

The prevalence of maxillary alveolar fracture was 81 (17.01\%). furthermore, the most commonly affected location was anterior area $(n=42,8.8 \%)$ followed by posterior area $(\mathrm{n}=27,5.5 \%)$, and anterior-posterior area $(\mathrm{n}=12,2.5 \%)$. Our study showed that in the age of 21-30 years the prevalence of maxillary alveolar fractures was more common in the anterior region $(\mathrm{n}=12$, $14.8 \%)$. However, a negative correlation and insignificant association were found between maxillary alveolar fractures and age groups $(\mathrm{r}=-0.042, p$ value $=0.711)$ (Table 2). Our results show that anterior maxillary alveolar fracture commonly accompanied by injuries in the nasal-zygoma-lefort of facial bone $(n=8,14.5 \%)$, but a negative correlation and insignificant association were found between them $(r=-0.188, p$ value $=0.17)$. prevalence of maxillary alveolar fracture based on mandibular fractures showed that anterior maxillary alveolar fracture was frequently accompanied with injuries in the body of the mandible $(n=6,26.1 \%)$ and but a negative correlation and insignificant association were found between them $(\mathrm{r}=-0.347, p$ value $=0.105)$.

Table 3 shows that the prevalence of maxillary alveolar fractures was more common in the male with anterior trauma $(n=36,44.4 \%)$. Besides, there was a negative correlation between maxillary alveolar fractures and gender $(r=-0.40)$ though, it was not significant (P-value $=0.723)$.

Generally, patients with anterior maxillary alveolar trauma caused by motorcycle vehicle accidents had the highest number $(\mathrm{n}=18,22.2 \%)$. However, a negative correlation and insignificant association were found between etiology and type of maxillary alveolar fractures $(\mathrm{r}=0.048$ and $p$-value $=0.67)($ Table 4$)$.

A total of 84 patients $(17.61 \%)$ had mandibular alveolar fractures. The most common fracture site was anterior region $(\mathrm{n}=41,8.6 \%)$ followed by posterior region $(\mathrm{n}=32$, $6.7 \%)$, and anterior-posterior ( $\mathrm{n}=11,2.3 \%)$. It was found that in the age of 21-30 years the prevalence of mandibular alveolar fractures in the anterior and posterior site was even $(n=13,15.4 \%)$. Besides, there was a negative correlation between mandibular alveolar fractures and age groups $(\mathrm{r}=-0.085)$ however, it was not significant $(P$ value $=0.44)($ Table 2$)$. Our results show that anterior mandibular alveolar fracture was commonly accompanied by injuries in the nasal-zygoma-lefort of facial bone $(\mathrm{n}=6,14.6 \%)$ still a negative correlation and insignificant association was found between them $(\mathrm{r}=-0.160$, $p$-value $=0.31)$. Prevalence of mandibular alveolar fracture based on maxillary fractures showed that anterior mandibular alveolar fracture frequently accompanied with injuries in the symphysis of the mandible $(n=16$, $33.3 \%$ ) and but a negative correlation and insignificant association found between them $(r=-0.181$, $p$-value $=0.219$ )

Table 3 shows that the prevalence of mandibular alveolar fractures was more common in the male with trauma in the anterior site $(n=34,40.5 \%)$. Additionally, there was a negative correlation between mandibular alveolar fractures and gender $(\mathrm{r}=-0.085)$ though, it was not significant $(P$-value $=0.44)$.

Overall, patients with anterior mandibular alveolar trauma caused by motorcycle vehicle accidents had the highest number $(\mathrm{n}=19,22.6 \%)$. However, a negative correlation and insignificant association were found between etiology and type of mandibular alveolar fractures $(\mathrm{r}=-0.087$ and $p$-value $=0.43)($ Table 4$)$.

\section{Discussion}

Alveolar fractures are frequent among people due to enhancements in technology and the increase in the use of motor vehicle equipment. Early diagnosis and appropriate management play an essential role in the success of the treatment and can prevent tooth or alveolar loss.

Although the leading causes of facial trauma are road crashes and violence, the relationship between these causes varies with culture, socioeconomic status, and geographic region [19]. Our study revealed that the most common cause of alveolar fractures was due to the car accident and the most minor common cause was violence. Many studies have reported road accidents as the leading cause of maxillofacial trauma [20-23]. Hongwei Wang et al. found that the most common etiologies of facial fractures were motor vehicle accidents (39.0\%), followed by high falling down (26.0\%), and low falling down 


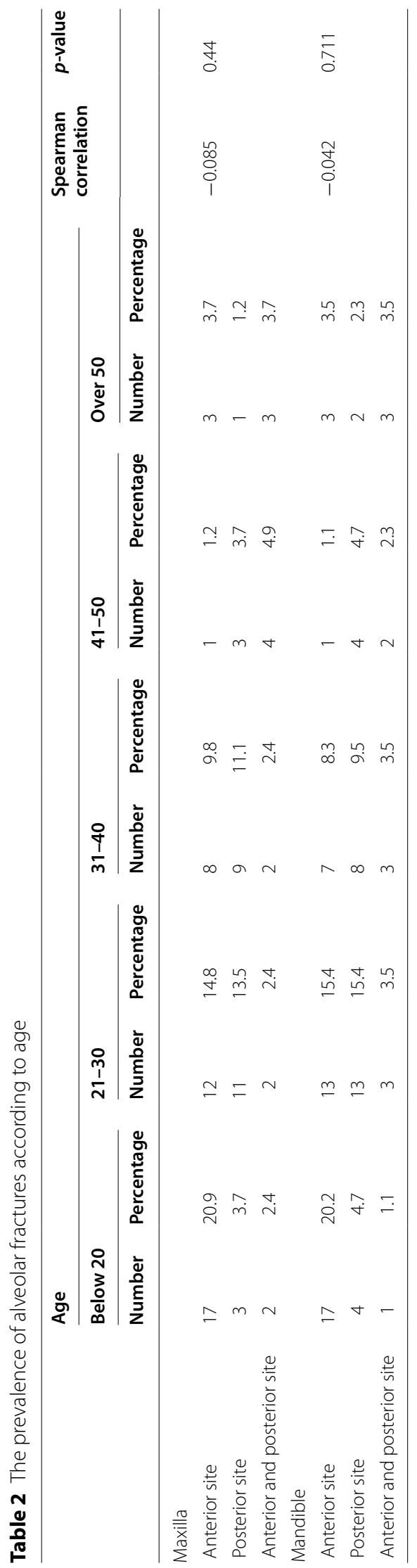


Table 3 The prevalence of alveolar fractures according to gender

\begin{tabular}{|c|c|c|c|c|c|c|}
\hline & \multicolumn{2}{|l|}{ Male } & \multicolumn{2}{|l|}{ Female } & \multirow{2}{*}{$\begin{array}{l}\text { Spearman } \\
\text { correlation }\end{array}$} & \multirow[t]{2}{*}{$p$-value } \\
\hline & Number & Percentage & Number & Percentage & & \\
\hline \multicolumn{7}{|l|}{ Maxilla } \\
\hline Anterior site & 36 & 44.4 & 6 & 7.4 & -0.40 & 0.723 \\
\hline Posterior site & 20 & 24.7 & 7 & 8.6 & & \\
\hline Anterior and posterior site & 7 & 8.6 & 5 & 6.2 & & \\
\hline \multicolumn{7}{|l|}{ Mandible } \\
\hline Anterior site & 34 & 40.5 & 7 & 8.3 & -0.085 & 0.44 \\
\hline Posterior site & 26 & 31 & 6 & 7.1 & & \\
\hline Anterior and posterior site & 29 & 35.4 & 4 & 4.8 & & \\
\hline
\end{tabular}

(20.8\%) [24]. One of the Iranian studies reported that the most and least common reasons for maxillofacial fracture were road accidents and falling, respectively [25].

On the other hand, most other studies revealed that falling and violence were the main causes of facial injuries [26, 27]. This strongly supports the fact that falls and accidents would be more associated with alveolar fractures in adults. This difference in the main etiology of facial fractures varies from one country to another. It can influence by age, culture, social and economic factors [28]. In children, falling, sports injuries, and bicycle injuries can be the main cause of alveolar fractures. But at an older age, violence, accidents, falling, and work-related injuries can be the main cause of facial trauma [29].

The ratio of men to women was $78.6 \%$ to $21.2 . \%$ in our study. This is consistent with previous studies indicated that maxillofacial trauma is more frequent in men [30-33]. However, studies reported that women have a higher risk of maxillofacial fractures with dental trauma [34]. This report suggested that men are prone to alveolar injuries due to the more likely to be present in the community, face violence, and have more car-related occupations. A Swedish investigation found a positive relationship between violence and drinking among youth. Alcohol consumption among younger men can connect to violence; therefore, it could be a reason for the higher incidence of alveolar fractures [35].

In most studies, the highest incidence of alveolar fractures found in youth $[36,37]$. In our study, the means age of men and women was $26.58 \pm 10.08$ and $30.03 \pm 11$ resepctively. Our results show that most people with alveolar fractures were between 21 and 30 years old. The gender and age distribution are very similar to previous studies, indicated that young men are the vast majority of patients with alveolar fractures [38, 39]. Also, with the increase in age, the prevalence of alveolar injuries is going to be decreased [36, 37].
In this research, a total number of 165 (34.5\%) had alveolar fractures for three years. Studies showed that trauma accounts for $5.5 \%$ of bone alveolar fractures, and $47-58 \%$ for soft tissue injuries [40, 41]. Another study of fractures in pediatric patients during 15 years reported that mandibular fractures were the most common (56\%), then alveolar bone fractures (31\%) [42]. At the Osaka University Dental Hospital, the most common form of maxillofacial injury was mandibular fractures (56\%), followed by alveolar fractures (31\%) [43]. An alveolar bone fracture can involve both dentate and edentulous arches [11]. In most cases, alveolar fractures and dental trauma occur simultaneously and the treatment of alveolar bone influences the treatment of teeth [34]. Alveolar fractures accompanied by dental fractures are more complicated in children than adults [34].

In our investigation, the prevalence of mandibular and maxillary alveolar fracture was $17.61 \%$ and $11.1 \%$, respectively and most of their trauma was anterior site. This is compatible with other studies that reported the anterior maxilla and mandible are common sites due to the location and vulnerability of these regions [44]. Incisor overjet, proclination, and incompetent lips of the upper arch and the low bone density of the anterior mandible make the anterior site of both jaws more prone to alveolar fracture $[11,45]$.

In most of the patients, alveolar fractures occurred with other facial bone fractures. Ruslin et al. stated that fractures are more common in the lower third of the face [34]. However, some researchers found that the upper two-thirds of the face are more susceptible to fractures $[46,47]$. Previous studies found that the most common sites of fracture are mandibular bone, followed by zygomatic and orbital bone [48]. Furthermore, the mandibular fractures tend to happen more often in, condyle and body respectively [48].

Alveolar trauma needs special attention in geriatric patients due to some physiological changes in the elderly 


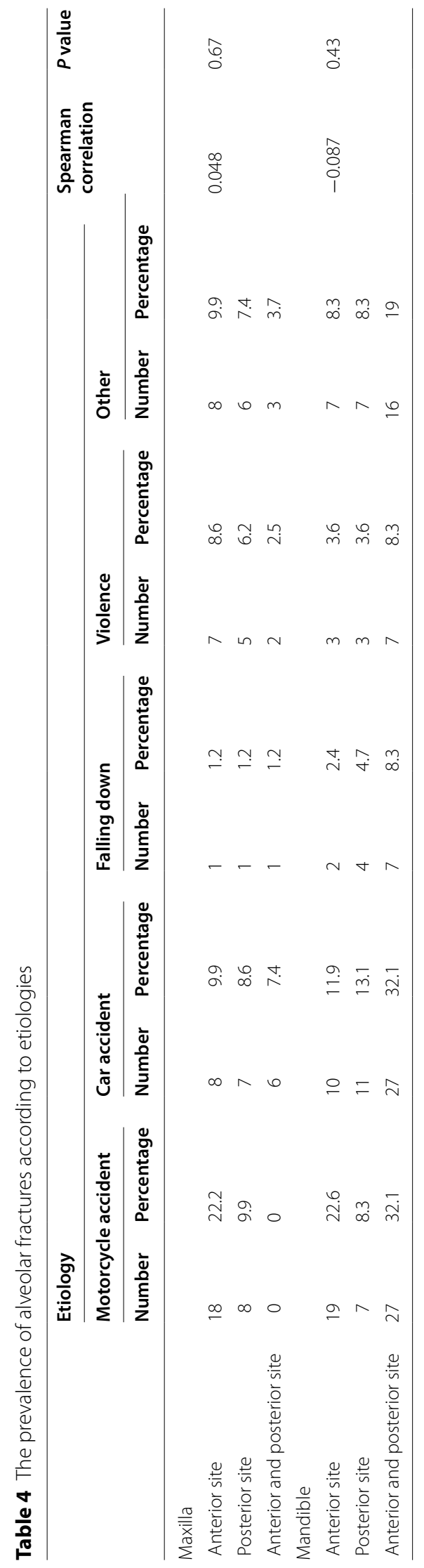


population such as bone atrophy, inadequate blood supply, and postponement in tissue repair [49]. In the above 70 years old individuals, facial trauma is progressively more frequent in women than in men due to the longer life of women [50]. The previous investigation stated that falls are the most frequent cause of maxillofacial trauma in the geriatric population [50]. The surgical management of alveolar fractures in elderly patients should be focused not only on the maxillofacial site but also on the other parts of the body that may need complex multidisciplinary management [49].

The results of our study may have been affected by some limitations. One of the most critical weaknesses of our study is that all cases in this research were patients that referred to the Rajaee hospital, and the sample might not include the whole population. Another restriction is that all of our participants were Iranian, while patients from different countries should be examined to find etiological factors of facial trauma. The differences between age, gender, and etiologies should analyzed to see the differences. The most common day of the week or time of the year that patients suffer from maxillofacial trauma could be evaluated to see an association between facial trauma and particular time like holidays. A rise in the number of participants of both genders and different age range recommended to evaluate alveolar fractures.

\section{Conclusion}

This study showed that alveolar trauma is one of the most common injuries among trauma patients. The most crucial incidence factor of these injuries is road accidents, and the majority of patients are young men; however, the prevalence of alveolar fractures is going to decrease with age. Early diagnosis and treatment plans are necessary to reduce the complications after facial trauma. Early training for young adults is vital to prevent the severity of trauma.

\section{Abbreviations}

CT: Computed Tomography; HIS: Hospital Information System; SPSS: Statistical Package for Social Sciences.

\section{Acknowledgements}

This article is prepared based on the thesis written by Dr. Mohammad Khalili.

\section{Authors' contributions}

FG and MK conceived and designed the study. MK collected data wrote the manuscript. HA performed the data analysis and assisted in the writing of the paper. All authors read and approved the final manuscript.

\section{Funding}

The authors received no financial support for the research and authorship.

\section{Availability of data and materials}

The datasets generated during and/or analysed for the current study are available from the corresponding author on reasonable request.

\section{Declarations}

Ethics approval and consent to participate

Written informed consent was obtained from the participants and their anonymity was guaranteed. The study protocol was approved by the institutional research board (IRB) and the medical ethics committee of the Shiraz University of Medical Sciences by the IRB number 1399.081REC.AL IR. SUMS.DENT.

\section{Consent for publication}

Not applicable.

\section{Competing interests}

The authors declare that they have no competing interests.

\section{Author details}

'Department of Oral and Maxillofacial Surgery, School of Dentistry, Shiraz University of Medical Sciences, Shiraz, Iran. ${ }^{2}$ Student Research Committee, Shiraz University of Medical Sciences, Shiraz, Iran.

Received: 1 June 2021 Accepted: 27 September 2021

Published online: 06 October 2021

\section{References}

1. Erdmann D, Follmar KE, DeBruijn M, Bruno AD, Jung SH, Edelman D, et al. A retrospective analysis of facial fracture etiologies. Ann Plast Surg [Internet]. 2008 [cited 2021 Apr 5];60(4):398-403. Available from: https:// pubmed.ncbi.nlm.nih.gov/18362568/

2. Pollansky sllva Farlas I, de Macedo Bernardlno Í, Marques da nóBrega lorena, grotta greMPel raFael. Maxillofacial trauma, etiology and profile of patients: an exploratory study traumas maxilofaciais, etiologia e perfil dos pacientes: um estudo exploratório work conducted at the Hospital of Emergency and Trauma Dom Luíz Gonzaga Fernandes. 2017:25(6):258-61.

3. Hussain K, Wijetunge DB, Grubnic S, Jackson IT. A comprehensive analysis of craniofacial trauma. J Trauma - Inj Infect Crit Care [Internet]. 1994 [cited 2021 Apr 11];36(1):34-47. Available from: https://pubmed.ncbi.nlm.nih. gov/8295247/

4. Schultz K, Braun T, surgery TT-S in plastic, 2017 undefined. Facial Trauma: Frontal Sinus Fractures. ncbi.nlm.nih.gov [Internet]. [cited 2021 Apr 5]; Available from: https://www.ncbi.nlm.nih.gov/pmc/articles/PMC54 23803/

5. Luis Muñante-Cárdenas J, Olate S, Asprino L, Ricardo De Albergaria Barbosa J, De Moraes M, Moreira RWF. Pattern and treatment of facial trauma in pediatric and adolescent patients. 2011;

6. Montovani JC, de Campos LMP, Gomes MA, de Moraes VRS, Ferreira FD, Nogueira EA. Etiology and incidence facial fractures in children and adults. Braz J Otorhinolaryngol. 2006;72(2):235-41.

7. Haug RH, Foss J. Maxillofacial injuries in the pediatric patient. Oral Surg Oral Med Oral Pathol Oral Radiol Endod [Internet]. 2000 [cited 2021 Apr 11];90(2):126-34. Available from: https://pubmed.ncbi.nlm.nih.gov/10936 829/

8. Braun T, Xue A, surgery RM-S in plastic, 2017 undefined. Facial Trauma: Differences in the management of pediatric facial trauma. ncbi.nlm.nih. gov [Internet]. [cited 2021 Apr 7]; Available from: https://www.ncbi.nlm. nih.gov/pmc/articles/PMC5423796/

9. Braun T, Xue A, surgery RM-S in plastic, 2017 undefined. Facial Trauma: Differences in the Management of Pediatric Facial Trauma. ncbi.nlm.nih. gov [Internet]. [cited 2021 Apr 5]; Available from: https://www.ncbi.nlm. nih.gov/pmc/articles/PMC5423796/

10. Mendonca D, Kenkere D. Avoiding occlusal derangement in facial fractures: An evidence based approach [Internet]. Vol. 46. Indian J Plastic Surg. Thieme Medical Publishers; 2013 [cited 2021 Apr 10]. p. 215-20. Available from: /pmc/articles/PMC3901902/

11. Gutmacher Z, Peled E, Norman D, Lin S. Alveolar Bone Fracture: Pathognomonic sign for clinical diagnosis. Open Dent J [Internet]. 2017 [cited 2021 May 13];11(1):8-14. Available from: /pmc/articles/PMC5362980/

12. Mampilly MO, Rao LP, Sequiera J, Sripathi Rao BH, Chandra J, Rai G. Rehabilitation of edentulous atrophic anterior mandible - the role of 
vertical alveolar distraction osteogenesis. J Clin Diagnostic Res [Internet]. 2014 [cited 2021 May 11];8(11):ZR01-3. Available from:/pmc/articles/ PMC4290354/

13. Dale RA. Dentoalveolar trauma. Emerg Med Clin North Am. 2000;18(3):521-38.

14. Moule A, Cohenca N. Emergency assessment and treatment planning for traumatic dental injuries. Aust Dent J [Internet]. 2016 Mar 1 [cited 2021 May 6];61:21-38. Available from: https://onlinelibrary.wiley.com/doi/ full/https://doi.org/10.1111/adj.12396

15. Peeters N, Lemkens $P$, Leach R, Gemels B, Schepers S, Lemmens W. Facial trauma [Internet]. Vol. Suppl 26, B-ENT. B-ENT; 2016 [cited 2021 Apr 7]. p. 1-18. Available from: https://pubmed.ncbi.nlm.nih.gov/29558572/

16. Abhinav RP, Selvarasu K, Maheswari G, Taltia A. The patterns and etiology of maxillofacial trauma in South India. Ann Maxillofac Surg [Internet]. 2019 [cited 2021 Apr 7];9(1):114-7. Available from:/pmc/articles/ PMC6585204/

17. Andreasen JO, Borum MK, Jacobsen HL, Andreasen FM. Replantation of 400 avulsed permanent incisors. 4. Factors related to periodontal ligament healing. Dent Traumatol [Internet]. 1995 [cited 2021 May 13];11(2):76-89. Available from: https://pubmed.ncbi.nIm.nih.gov/76416 221

18. Far AS, Zargar M, Mohammad Reza Kalantar Motamedi S, Karbakhsh M, Mohammad Ghodsi S, Rahimi-Movaghar V, et al. Trauma care system in Iran. Chinese J Traumatol. 2011;14(3):131-6.

19. Afzelius LE, Rosén C. Facial fractures: a review of 368 cases. Int J Oral Surg [Internet]. 1980 [cited 2021 Apr 27];9(1):25-32. Available from: https:// pubmed.ncbi.nlm.nih.gov/6769827/

20. Villarreal PM, Monje F, Junquera LM, Mateo J, Morillo AJ, González C. Mandibular condyle fractures: determinants of treatment and outcome. J Oral Maxillofac Surg [Internet]. 2004 [cited 2021 May 4];62(2):155-63. Available from: https://pubmed.ncbi.nlm.nih.gov/ $14762747 /$

21. Motamedi MHK. An assessment of maxillofacial fractures: A 5-year study of 237 patients. J Oral Maxillofac Surg [Internet]. 2003 Jan 1 [cited 2021 May 4];61(1):61-4. Available from: https://pubmed.ncbi. nlm.nih.gov/12524610/

22. Bataineh $A B$. Etiology and incidence of maxillofacial fractures in the north of Jordan. Oral Surg Oral Med Oral Pathol Oral Radiol Endod [Internet]. 1998 [cited 2021 May 4];86(1):31-5. Available from: https:// pubmed.ncbi.nlm.nih.gov/9690242/

23. Subhashraj K, Ramkumar S, Ravindran C. Pattern of mandibular fractures in Chennai, India. Br J Oral Maxillofac Surg [Internet]. 2008 Mar [cited 2021 May 4];46(2):126-7. Available from: https://pubmed.ncbi. nlm.nih.gov/17098339/

24. Wang H, Song G, Ren W, Zhou Y, Li C, Ou L, et al. Traumatic facial fractures in children and adolescents. J Craniofac Surg [Internet]. 2018 [cited 2021 May 4];29(7):1809-12. Available from: https://pubmed.ncbi. nlm.nih.gov/30234718/

25. Akrami S, Navab Azam A, Akaberi F. Epidemiologic investigation of maxillofacial fractures in admitted patients in Yazd trauma centers (2005-2011). Yazd Journal of Dental Research-The Journal of Faculty of Dentistry Shahid Sadoughi University of Medical Sciences (quarterly). 2014;2(1):46-60. - Google Search [Internet]. [cited 2021 May 4]. Available from: https://www.google.com/search?q=Akrami+S\% $2 \mathrm{C}+\mathrm{Navab}+\mathrm{Azam}+\mathrm{A} \% 2 \mathrm{C}+$ Akaberi+F.+Epidemiologic+investigat ion+of+maxillofacial+fractures+in+admitted+patients+in+Yazd+ trauma+centers+(2005-2011). +Yazd+Journal+of+Dental+ResearchThe+Journal+of+Faculty+of+Dentistry+Shahid+Sadoughi+Unive rsity+of+Medical+Sciences+(quarterly).+2014\%3B2(1)\%3A46-60.\& $\mathrm{oq}=\mathrm{Akrami}+\mathrm{S} \% 2 \mathrm{C}+\mathrm{Navab}+\mathrm{Azam}+\mathrm{A} \% 2 \mathrm{C}+$ Akaberi+F.+Epidemiolo gic+investigation+of+maxillofacial+fractures+in+admitted+patie nts+in+Yazd+trauma+centers+(2005-2011). +Yazd+Journal+of+ Dental+Research-The+Journal+of+Faculty+of+Dentistry+Shahid+ Sadoughi+University+of+Medical+Sciences+(quarterly).+2014\% 3B2(1)\%3A46-60.\&aqs=chrome.0.69i59j69i60.1023j0j4\&sourceid= chrome\&ie $=$ UTF-8

26. Li Z, Li ZB. Characteristic changes of pediatric maxillofacial fractures in china during the past 20 years. J Oral Maxillofac Surg [Internet]. 2008 [cited 2021 May 4];66(11):2239-42. Available from: https://pubmed. ncbi.nlm.nih.gov/18940486/
27. Gassner R, Tuli T, Hächl O, Moreira R, Ulmer H. Craniomaxillofacial Trauma in Children: a review of 3385 cases with 6060 injuries in 10 years. J Oral Maxillofac Surg. 2004;62(4):399-407.

28. Ahmed HE Al, Jaber MA, Abu Fanas SH, Karas M. The pattern of maxillofacial fractures in Sharjah, United Arab Emirates: a review of 230 cases. Oral Surgery, Oral Med Oral Pathol Oral Radiol Endodontology [Internet]. 2004 [cited 2021 May 1];98(2):166-70. Available from: https://pubmed.ncbi.nlm.nih.gov/15316543/

29. Lin S, Levin L, Goldman S, Peled M. Dento-alveolar and maxillofacial injuries: a retrospective study from a level 1 trauma center in Israel. Dent Traumatol [Internet]. 2007 Jun [cited 2021 May 13];23(3):155-7. Available from: https://pubmed.ncbi.nlm.nih.gov/17355291/

30. Surgery AB-O, Medicine O, Pathology O, Oral undefined, 1998 undefined. Etiology and incidence of maxillofacial fractures in the north of Jordan. Elsevier [Internet]. [cited 2021 Apr 27]; Available from: https:// www.sciencedirect.com/science/article/pii/S1079210498901469

31. Akrami S, Azam AN, Research FA-YJ of D, 2014 undefined. Epidemiologic investigation of maxillofacial fractures in admitted patients in Yazd trauma centers (2005-2011). yjdr.ssu.ac.ir [Internet]. [cited 2021 Apr 27]; Available from: http://yjdr.ssu.ac.ir/article-1-26-en.html

32. Sakr K, Farag IA, Zeitoun IM. Review of 509 mandibular fractures treated at the University Hospital, Alexandria. Egypt Br J Oral Maxillofac Surg. 2006;44(2):107-11.

33. e Farias IPS, Bernardino ítalo de M, da Nóbrega LM, Grempel RG, D'Avila S. Maxillofacial trauma, etiology and profile of patients: An exploratory study. Acta Ortop Bras [Internet]. 2017 [cited 2021 Apr 27];25(6):25861. Available from: https://www.scielo.br/scielo.php?pid=\$1413-78522 $017000600258 \&$ script=sci_arttext

34. $M R, J W, P B, H S B, T F$. Dental trauma in association with maxillofacial fractures: an epidemiological study. Dent Traumatol [Internet]. 2015 Aug 1 [cited 2021 Jul 31];31(4):318-23. Available from: https://pubmed. ncbi.nlm.nih.gov/25892049/

35. Svensson J, alcoholism JL-A and, 2013 undefined. Is youth violence temporally related to alcohol? A time-series analysis of binge drinking, youth violence and total alcohol consumption in Sweden. academic. oup.com [Internet]. [cited 2021 May 4]; Available from: https://acade mic.oup.com/alcalc/article-abstract/48/5/598/209111

36. Epidemiology of mandibular fractures treated at Kaunas University of Medicine Hospital, Lithuania - Google Search [Internet]. [cited 2021 May 1]. Available from: https://www.google.com/search?q=Epide miology+of+mandibular+fractures+treated+at+Kaunas+Unive rsity+of+Medicine+Hospital\%2C+Lithuania\&oq=Epidemiology+of+ mandibular+fractures+treated+at+Kaunas+University+of+Medic ine + Hospital\%2C+Lithuania\&aqs $=$ chrome. $69157.1038 j 0 j 7 \&$ sourceid $=$ chrome\&ie $=$ UTF-8

37. Two Year Evaluation of Maxillofacial Fractures in Conventional Radiographs of Patients Referring to Radiology Department of Mashhad Dental School [Internet]. [cited 2021 May 1]. Available from: https:// jmds.mums.ac.ir/article_2107.html?lang=en

38. Lee KH. Epidemiology of mandibular fractures in a tertiary trauma centre. Emerg Med J [Internet]. 2008 [cited 2021 May 2];25(9):565-8. Available from: https://pubmed.ncbi.nlm.nih.gov/18723703/

39. Torgersen S, maxillofacial KT-I journal of oral and, 1992 undefined. Maxillofacial fractures in a Norwegian district. Elsevier [Internet]. [cited 2021 May 2]; Available from: https://www.sciencedirect.com/science/ article/pii/S0901502705807568

40. Çalişkan MK, Türkün M. Clinical investigation of traumatic injuries of permanent incisors in Izmir, Türkiye. Dent Traumatol [Internet]. 1995 [cited 2021 May 13];11 (5):210-3. Available from: https://pubmed.ncbi. nlm.nih.gov/8625933/

41. Bastone EB, Freer TJ, McNamara JR. Epidemiology of dental trauma: A review of the literature [Internet]. Vol. 45, Australian Dental Journal. Australian Dental Association Inc.; 2000 [cited 2021 May 13]. p. 2-9. Available from: https://pubmed.ncbi.nlm.nih.gov/10846265/

42. Iida S, Matsuya T. Paediatric maxillofacial fractures: Their aetiological characters and fracture patterns. J Cranio-Maxillofacial Surg [Internet]. 2002 [cited 2021 May 13];30(4):237-41. Available from: https://pubmed.ncbi.nlm.nih.gov/12231205/

43. Gassner R, Tuli T, Hächl O, Rudisch A, Ulmer H. Cranio-maxillofacial trauma: A 10 year review of 9543 cases with 21067 injuries. J 
Cranio-Maxillofacial Surg [Internet]. 2003 [cited 2021 May 14];31(1):5161. Available from: https://pubmed.ncbi.nlm.nih.gov/12553928/

44. Levin L, Friedlander LD, Geiger SB. Dental and oral trauma and mouthguard use during sport activities in Israel. Dent Traumatol [Internet]. 2003 Oct [cited 2021 May 14];19(5):237-42. Available from: https:// pubmed.ncbi.nlm.nih.gov/14708646/

45. Järvinen S. Incisal overjet and traumatic injuries to upper permanent incisors: A retrospective study. Acta Odontol Scand [Internet]. 1978 [cited 2021 May 14];36(5-6):359-62. Available from: https://pubmed. ncbi.nlm.nih.gov/281861/

46. Thoren H, Numminen L, Snäll J, Kormi E, Lindqvist C, lizuka T, Törnwall $J$. Occurrence and types of dental injuries among patients with maxillofacial fractures. Int J Oral Maxillofac Surg [Internet]. 2010 Aug [cited 2021 Jul 31];39(8):774-8. Available from: https://pubmed.ncbi.nlm.nih. gov/20435438/

47. Roccia F, Boffano P, Bianchi FA, Ramieri G. An 11-year review of dental injuries associated with maxillofacial fractures in Turin, Italy. Oral Maxillofac Surg [Internet]. 2013 Dec [cited 2021 Jul 31];17(4):269-74. Available from: https://pubmed.ncbi.nIm.nih.gov/23138750/

48. Boffano P, Roccia F, Zavattero E, Dediol E, Uglešić V, Kovačič Ž, et al. European Maxillofacial Trauma (EURMAT) project: A multicentre and prospective study. J Cranio-Maxillofacial Surg [Internet]. 2015;43(1):6270. Available from: https://www.sciencedirect.com/science/article/pii/ S1010518214002881

49. Brucoli M, Boffano P, Romeo I, Corio C, Benech A, Ruslin M, Forouzanfar T, Starch-Jensen T, Rodríguez-Santamarta T, de Vicente JC, Snäll J. Management of maxillofacial trauma in the elderly: a European multicenter study. Dent Traumatol [Internet]. 2020 Jun 1 [cited 2021 Aug 1];36(3):241-6. Available from: https://pubmed.ncbi.nlm.nih.gov/ 31863620/

50. Brucoli M, Boffano P, Romeo I, Corio C, Benech A, Ruslin M, Forouzanfar T, Starch-Jensen T, Rodríguez-Santamarta T, de Vicente JC, Snäll J. Epidemiology of maxillofacial trauma in the elderly: a European multicenter study. J Stomatol oral Maxillofac Surg [Internet]. 2020 Sep 1 [cited 2021 Aug 1];121(4):330-8. Available from: https://pubmed. ncbi.nlm.nih.gov/31533064/

\section{Publisher's Note}

Springer Nature remains neutral with regard to jurisdictional claims in published maps and institutional affiliations.
Ready to submit your research? Choose BMC and benefit from:

- fast, convenient online submission

- thorough peer review by experienced researchers in your field

- rapid publication on acceptance

- support for research data, including large and complex data types

- gold Open Access which fosters wider collaboration and increased citations

- maximum visibility for your research: over 100M website views per year

At BMC, research is always in progress.

Learn more biomedcentral.com/submissions 